\title{
Makalah
}

\section{PERBEDAAN KANDUNGAN ALBUMIN IKAN GABUS PADA BEBERAPA JENIS OLAHANNYA}

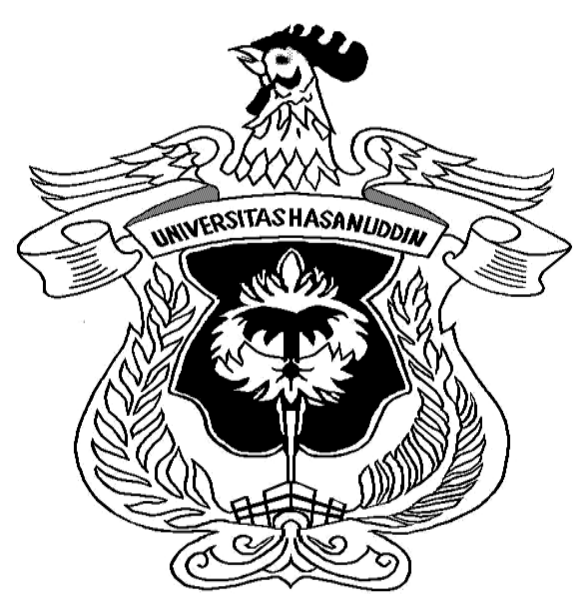

OLEH

\section{MUHAMMAD ASFAR}

UNIVERSITAS HASANUDDIN

MAKASSAR 


\section{PENDAHULUAN}

\section{A. Latar Belakang}

Ikan gabus (Ophiocephalus striatus) merupakan jenis ikan yang hidup di air tawar dan sudah banyak dikenal oleh masyarakat. Ikan gabus berkembang biak dan hidup di daerah sungai, sawah, empang dan sering juga ditemukan di daerah rawa.

Ikan gabus (Ophicepalus striatus) adalah ikan yang masih termasuk dalam ordo labyrinhiaci, pada kepalanya terdapat rongga-rongga penyimpanan udara untuk persediaan pernapasan. Tubuh ikan gabus panjang dan bulat, kepalanya seperti kepala ular, jenis ikan ini dapat hidup dalam air yang kotor dengan kadar oksigen yang rendah, bahkan tahan terhadap kekeringan. Makanannya berupa hewan-hewan lain seperti cacing, katak, anak-anak ikan, udang. Panjang tubuhnya dapat mencapai $100 \mathrm{~cm}$ dan hidup di muara-muara sungai serta danau. Ikan ini dapat diternak karena merupakan karnivora yang suka memakan ikanikan lain yang lebih kecil (Djuhanda, 1981)

Ikan gabus memang kurang digemari oleh masyarakat luas karena jarang di jual di pasar dan dianggap oleh masyarakat ikan jenis ini suka memakan kotoran dan bangkai hewan serta bentuknya yang seperti ular. 
Namun akhir-akhir ini banyak masyarakat yang mulai menyukai ikan gabus, karena mereka telah mengetahui kandungan gizi yang terdapat dalam ikan gabus sangat tinggi dan banyak faedahnya. Hal ini diketahui oleh masyarakat karena mereka terinspirasi dari orang-orang Cina yang mengobati luka bakar dengan memakan ikan gabus.

Menurut llyas (1980), bahwa komposisi kimia ikan bervariasi menurut spesies dan jenisnya. Adanya variasi dan komposisi kimia ikan disebabkan oleh perbedaan musim saat ikan ditangkap, area geografis, umur, jenis sex, ukuran dan kedewasaan seksual.

Afrianto dan Liviawati (1989), menjelaskan komponen kimia utama yang menyusun ikan terdiri dari air $60,0-84,0 \%$, protein $18,0-30 \%$, Lemak $0,1-2,2 \%$, karbohidrat $0,0-1,0 \%$ serta mineral. Sedangkan menurut Vaas (1956) dalam Tahir (1997), komposisi kimia ikan gabus terdiri dari air $77,0 \%$, protein $11,0 \%$, lemak $1,5 \%$, karbohidrat $0,2 \%$ serta mineral $1,3 \%$.

Hasil penelitian Johanes Cavallo, 1998, kandungan albumin per 100 cc ikan gabus adalah 6,224 gram dengan jumlah 69 kalori, 1,7412 mg seng, 3,093 mg glutamate, 1,1 mg arginin dan 3,2 mg BCAA. Sedangkan penelitian Abu Bakar, dkk. Bahwa kandungan tepung ikan gabus memiliki kadar protein albumin sebesar $15.79 \%$ dan kadar air $8.5 \%$. 
Dengan kandungan Albumin pada ikan gabus menyebabkan ikan gabus ini memiliki manfaat bagi kesehatan, Tim peneliti dari Universitas Brawijaya Malang yaitu Eddy Suprayitno (2003), melaporkan bahwa ikan gabus (Ophiocephalus strictus) merupakan sumber potensial protein albumin. Protein albumin pada ikan gabus mengandung semua asam amino esensial dan asam lemak unik untuk membantu mempercepat penyembuhan luka. Hasil uji klinis menunjukkan bahwa ekstrak kasar ikan gabus (Ophiocephalus strictus) dapat mempercepat proses penyembuhan luka pasien yang baru dioperasi dibandingkan dengan menggunakan protein albumin komersial.

Namun, pengolahan ikan gabus pada tingkat rumah tangga secara umum dalam tiga bentuk pengolahan yaitu diolah dengan cara dimasak, digoreng, dan dipanggang. Pengolahan ini ada yang hanya sekedar dijadikan sebagai lauk untuk makanan. Namun ada juga yang mengolahnya dan dikomsumsi sebagai obat karena kandungan Albumin yang terdapat didalamnya. Hal ini biasa di sebut dengan makanan fungsional. Oleh karena itu penelitian ini dilakukan untuk menguji kadar albumin ikan gabus dari pengolahan yang sering dilakukan secara umum pada tingkat rumah tangga yaitu di masak, digoreng dan dipanggang. 


\section{B. Perumusan Masalah}

Pergeseran pengetahuan tentang ikan gabus pada masyarakat akan manfaat dan kandungannya menyebabkan perubahan minat masyarakat untuk mengolah dan mengkomsumsi ikan gabus. Hal itu meraka harapkan agar dapat mengambil manfaat dan menjadikan obat dengan mengkomsumsi ikan gabus tersebut. Mereka mengharapkan ikan gabus bisa mempercepat penyembuhan luka dan beberapa penyakit dengan mengkomsumsi ikan tersenbut. Namun, kandungan protein albumin ikan gabus adalah bersifat protein yang mudah terdenaturasi dan larut air yang menyebabkan kandungannya rusak atau hilang. Sehingga dalam penelitian ini dilakukan untuk mengetahui seberapa besar kadar albumin dalam beberapa cara pengolahan secara umum yang sering dilakukan oleh masyarakat yaitu di masak, digoreng dan di panggang. 


\section{Tujuan dan Kegunaan Penelitian}

Tujuan penelitian ini adalah mengetahui kadar protein albumin pada ikan gabus dengan cara pengolahan yang umum dilakukan oleh masyarakat yaitu dimasak, di goreng dan di panggang.

Keguanaan penelitian ini adalah memberikan informasi mengenai kadar protein albumin pada ikan masak,dipanggang dan di goreng. Sehingga dapat diketahui mana cara pengolahan yang terbaik. 


\section{TINJAUAN PUSTAKA}

\section{A. Ikan Gabus (Ophiocephalus striatus)}

Secara taksonomi dan sistematis Weber dan Beaufort (1922), direvolusi oleh $\mathrm{Ng}$ dan $\mathrm{Li}$ di dalam Kottelat et al., (1993), di dalam Bijaksana (2004), mengklasifikasikan ikan gabus dalam

$\begin{array}{ll}\text { Kingdom } & : \text { Animalia } \\ \text { Phylum } & : \text { Chordata } \\ \text { Sub Phylum } & : \text { Vertebrata } \\ \text { Klas } & : \text { Pisces } \\ \text { Sub Klas } & : \text { Teleostei } \\ \text { Ordo } & : \text { Labyrinthychy } \\ \text { Family } & : \text { Channidae } \\ \text { Genus } & : \text { Channa striata (KotteLat et al., 1993) } \\ \text { Spesies } & : \text { Ophiohepalus striatus } \\ \text { Synonim } & : \text { Head Snake } \\ \text { Nama Inggris } & \\ \text { Nama Indonesia } & \text { Ikan Gabus }\end{array}$


Ikan gabus memiliki bentuk tubuh Sub-cylindrical, kepala depressed dan sirip ekor rounded. Bagian permukaan dan samping punggung berwarna gelap dan bercorak kombinasi warna hitam dan kuning tua, putih pada bagian perut.

Ikan gabus banyak ditemukan di sungai-sungai dan rawa. Kadangkadang terdapat di air payau berkadar garam rendah. Ikan ini hidup di muara-muara sungai, danau dan dapat pula hidup di air kotor dengan kadar oksigen rendah, bahkan tahan terhadap kekeringan. Ikan gabus juga dapat ditemukan di berbagai perairan umum di Indonesia di antaranya Jawa, Sumatra, Sulawesi, Bali, Lombok, Flores, Ambon dan Maluku dengan nama yang berbeda (Brotowijoyo, 1995).

Ikan mengandung asam lemak jenuh yang jumlahnya lebih rendah dibanding jenis binatang menyusui dan kandungan asam lemak tidak jenuh yang lebih banyak. Ikan mengandung pula protein yang berkualitas tinggi. Protein dalam ikan tersusun dari asam amino yang dibutuhkan oleh tubuh untuk pertumbuhan. Selain itu protein ikan mudah dicerna dan diabsorbsi. Pada daging ikan terdapat senyawasenyawa yang sangat potensial bagi tubuh manusia, dimana secara kimiawi unsur-unsur organik daging ikan adalah 75\% oksigen, $10 \%$ hidrogen, 9,5\% karbon dan 2,5\% nitrogen. Unsur-unsur tersebut terdiri dari protein, lemak, sedikit karbohidrat, vitamin, dan garam mineral (Irawan, 1997) 
Afrianto dan Liviawati (1989), menjelaskan bahwa komponen kimia utama yang menyusun ikan terdiri dari air $60,0 \%-84 \%$, Protein $18,0-$ $30 \%$ protein, lemak 0,1-2,2 \%, karbohidrat $0,0-1,0 \%$ serta mineral.Sedangkan menurut Vaas (1956) dalam Tahir M (2004), bahwa komposisi kimia ikan gabus terdiri dari air $77,0 \%$, protein $11,0 \%$, lemak $1,5 \%$ serta mineral $1,3 \%$.

Ikan merupakan sumber bahan pangan dan sumber protein hewani yang sangat tinggi. Pada daging ikan terdapat senyawa-senyawa yang sangat potensial bagi tubuh manusia. Dimana secara kimiawi unsurunsur kimiawi organik ikan adalah 75\% oksigen, 10\% hidrogen, 9,5\% karbon dan 2,5\% nitrogen. Unsur-unsur tersebut terdiri dari protein, lemak, sedikit kabohidrat, vitamin dan mineral. Unsur protein merupakan yang terbesar dalam kandungan daging ikan sehingga merupakan sumber protein hewani yang sangat potensial. Selain itu ikan mengandung asam amino esensial, vitamin A dan B yang sangat dibutuhkan oleh tubuh, dan ada beberapa jenis ikan yang memiliki kandungan lemak yang tinggi.

\section{B. Albumin}

Albumin adalah protein yang larut dalam air, mengendap pada pemanasan. la dibuat oleh hati dan merupakan salah satu konsituen utama tubuh. Kalau anda sulit membayangkan rupa albumin, bayangkanlah putih telur. Albumin dan protein serum lainnya dihasilkan 
oleh hati dan merupakan faktor penting dalam pertahanan tekanan cairan yang normal pada pembulu darah dan lingkungan sel (Anonim, 2005)

Albumin merupakan molekul biologi dengan fungsi utama adalah (1) sebagai pengangkut ion-ion $\mathrm{Ca}^{+}$, asam lemak, empedu, bilirubin dan heamatin didalam darah, (2) mempertahankan tekanan osmosis koloid (COP) dan volume darah (Peter, 1997). Protein albumin adalah komponen utama protein yang terkandung dalam plasma, sekitar $60 \%$ dari total plasma $3,5-5,5 \mathrm{~g} / \mathrm{L}$

Protein albumin manusia mempunyai bobot molekul 66.500 Dalton, terdiri dari rantai polipeptida tunggal dari 585 residu asam amino. Rantai polipeptida protein albumin tidak mempunyai molekul karbohidrat (Karbohidrate moety), sebagian besar residu asam aminonya merupakan residu asam amino bermuatan lisin, arginin, asam glutamat, dan asam aspartat (Crespo, dkk., 2000).

Albumin merupakan nama umum dari sekelompok protein yang berupa larutan koloid. Albumin merupakan unsur utama yang terdapat pada putih telur (ovalbumin), merupakan unsur penting dalam serum darah (Serum Albumin), juga terdapat dalam susu (Lactalbumin), jaringan dan cairan fisiologis, dan dalam tumbuhan (Vegetable Albumin). Komposisi asam amino dala albumin bervariasi, tergantung pada asal bahan dasarnya. Hasil beberapa analisis menunjukkan 
bahwa albumin telur mengandung $54,3 \%$ sulfur. Albumin dapat bergabung dengan beberapa logam berat, maka digunakan sebagai penangkal pada keracunan garam-garam merkuri. Albumin dapat terkoagulasi atau terdenaturasi oleh panas, alkohol, atau asam. Koagulasi juga akan mengendapkan padatan tersuspensi, sifat inilah yang menyebabkan albumin digunakan untuk menjernihkan produk seperti wine, sirup, dan sebagainya (Makfoed, dkk., 2002)

Kadar albumin plasma merupakan indeks yang dapat dipercaya untuk menentukan perubahan kondiovaskuler pada penderita gizi buruk. Banyaknya penderita gizi buruk dengan kelainan EKG nampaknya berkurang dengan meningkatnya kadar albumin serum. Kadar albumin 1,5 g/dl merupakan suatu tingkat kritis, dibawah nilai inilah akan terjadi kegagalan sirkulasi yang berat (Anonim, 2005).

Albumin juga berperan sebagai mengikat obat-obatan yang tidak mudah larut, seperti aspirin, antikoagulan, koumarin, dan obat tidur. Selain mengobati luka bakar dan luka pasca oprasi, albumin bisa digunakan untuk menghindari timbulnya sembab paru-paru dan ginjal, serta carrier faktor pembekuan darah (Anonim, 2003)

Salah satu sumber daya hayati yang banyak melimpah dan kaya akan protein albumin adalah ikan gabus (Ophiocephalus strictus). Dalam dunia kedokteran, ikan gabus memiliki manfaat yang besar. Baru-baru ini telah diteliti oleh Eddy Suprayitno yang merupakan guru 
besar pertama untuk Fakultas Perikanan Universitas Brawijaya, bahwa ikan gabus mempunyai kandungan albumin yang tinggi dan bisa menyembuhkan luka operasi. Hal ini karena ikan gabus mengandung asam amino assential yang sangat lengkap. Namun ikan gabus tersebut harus dimasak dengan cara khusus. Caranya, ikan gabus diambil ekstraknya dengan mengukusnya, lalu menampung airnya di bawah saringan. Air yang keluar dari ikan itulah ekstraknya (Anonimous, 2003). Namun demikian pemanfaatan ikan gabus dalam bentuk tepung sebagai bahan makanan tambahan pada pasien belum pernah dilaporkan.

Di Malaysia, penelitian tentang protein albumin dari ikan gabus untuk keperluan medis juga intensif dilakukan. Keuntungan food supplement tepung ikan gabus yang kaya akan protein albumin adalah karena harga terjangkau dan bahan baku mudah diperoleh. Penelitian saat ini banyak berkaitan dengan penanggulangan Hipoalbuminemia melalui pemberian ektrak ikan gabus.

\section{Pengolahan Pangan dengan Panas}

Kebanyakan bahan pangan terasa sangat nikmat dikonsumsi segera setelah diolah tanpa ada tenggang waktu tunggu. Buah dan sayur segar akan kehilangan vitamin yang bernilai tinggi jika disimpan beberapa waktu lamanya. Bahan pangan segar yang tidak segera 
diolah dan dimakan, sedapat mungkin disimpan dalam waktu yang singkat.

Mengkonsumsi bahan segar menurut para ahli gizi jauh lebih baik daripada bahan olahan. Namun demikian tidak semua bahan pangan dapat dikonsumsi dalam keadaan segar atau mentah. Beberapa di antaranya kurang lezat jika tidak dimasak terlebih dahulu, bahkan ada pula yang masih mengandung racun. Beberapa sayuran seperti kentang dan legum tentuhya harus dimasak hingga matang sebelum dikonsumsi. Pati kentang yang mentah tidak dapat dicerna oleh tubuh. Kacang mentah sebagai contoh, banyak yang mengandung toksin, sementara kacang yang telah dimasak akan menjadi makanan yang sehat karena toksin yang tidak tahan panas pada kacang akan rusak selama proses pemasakan. Jarang ada orang yang mau mengkonsumsi serealia dan umbi-umbian mehtah, karena karbohidrat yang ada di dalamnya baru dapat dicerna setelah melalu proses pemasakan. Senyawa [3-karoten (provitamin A) pada wortel dapat terserap oleh tubuh secara lebih baik dalarn keadaan matang dibandingkan dalam keadaan mentah. Demikian pula senyawa likopen pada tomat yang bersifat antioksidan.

Pemasakan akan mengubah warna bahan mentah, udang yang semula berwarna abu-abu akan menjadi merah, daging yang semula merah menjadi berwarna coklat, sayuran hijau jika dimasak terlalu lama 
akan berubah menjadi pucat, mentega atau margarine yang berwarna kuning berubah menjadi coklat kemudian hitam (Mizer et al., 2000).

\section{Pemasakan}

Melalui pemasakan, struktur serat bahan akan menjadi lunak dan elastis, aroma dan citarasa akan terbentuk, bahan pangan akan lebih mudah dikunyah dan dicerna. Bentuk dan kenampakan bahan pangan sebaiknya tetap dipertahankan, kecuali untuk tujuan khusus seperti pembuatan bubur yang mengharuskan semua bahan dihaluskan sehingga bentuk aslinya tidak lagi nampak. Cara pemasakan yang keliru akan menyebabkan kehilangan zat gizi yang lebih banyak.

Melalui pemasakan, sebagian besar senyawa yang tidak diinginkan akan hilang, baik senyawa anti gizi maupun senyawa beracun. Sebagian besar makanan bahkan baru dapat mem'mbulkan aroma dan citarasa yang merangsang setelah melalui pemasakan yang membantu memperbaiki daya cerna masakan tersebut.

Pemasakan menyebabkan protein dalam bahan pangan mengalami koagulasi sehingga menjadi keras dan menyatu. Hal ini dapat dengan jelas terlihat pada proses penggorengan telur dengan panas yang rehdah. Cairan putih telur yang transparan perlahan befubah menjadi putih dan padat saat suhu panas telah tercapai. Jika telur dimasak atau digoreng terlalu lama atau suhu terlalu tinggi akan 
menjadi terlalu keras dan liat. Hal yang sama terjadi pada pemasakan daging. Ketika suhu pemanasan meningkat protein akan mengeras. Pemasakan yang terlalu lama akan menyebabkan daging menjadi liat. Pada suhu pemanasan sampai 70 "C terjadi peningkatan keliatan daging. Setelah suhu lebih dari $80^{\circ} \mathrm{C}$ daging akan menjadi lunak. Di bawah pengaruh panas kering $\left(60^{\circ}-65^{\circ} \mathrm{C}\right)$ kolagen akan menyusut dan potongan daging mengecil. Selanjutnya terjadi pengurangan bobot sebesar $20 \%$ karena otot terperas. Pada suhu $80^{\circ}-90^{\circ} \mathrm{C}$ kolagen mulai berubah menjadi gelatin yang mengarah pada pelunakan daging. Pada kisaran suhu ini terjadi reaksi pencoklatan (Schwedt, 2005).

Hewan muda mengandung kolagen yang lebih mudah larut dalam air dan tidak tahan panas daripada hewan yang lebih tua. Ketika dimasak, kolagen akan rusak dan tidak menyebabkan kekerasan. Pada hewan yang tua, kolagen menjadi tahan panas sehingga tidak pecah pada saat pemasakan, akibatnya daging akan keras. Otot yang banyak bergerak mengandung lebih banyak kolagen yang tahan panas (Vieira, 1996).

\section{Dibakar}

Perbedaan utama antara pemanggangan dan pembakaran adalah bahwa pembakaran dilakukan langsung di atas bara api. Bahan pangan matang ditandai dengan warna kecoklatan bahkan kehitaman yang tidak 
merata, tergantung letak bahan terhadap bara api. Bahan pangan yang dibakar dapat diletakkan langsung di atas potongan besi atau kayu sebagai dudukan yang akan menghubungkan bahan dengan bara api. Selain itu bahan pangan dapat terlebih dahulu dibungkus dengan daun pisang atau kertas aluminium (aluminium foil) untuk mencegah terjadinya penetesan cairan lemak dari bahan ke atas bara api. Reaksi antara tetesan lemak dengan bara api akan menghasilkan asap yang kemungkinan mengandung senyawa-senyawa berbahaya dari kelompok polisiklis aromatis hidrokarbon (PAH) seperti 1,2-benzpiren (benzo(a)piren)

Pada pembakaran menggunakan alat pembakar elektrik di mana suhu dapat diatur pada $200^{\circ} \mathrm{C}$, hal tersebut tidak perlu dirisaukan. Berbeda jika pada panas yang tinggi hingga $500^{\circ} \mathrm{C}$, maka pembentukan senyawa penyebab kanker tersebut di atas dapat saja terjadi. Pada produk daging dan ikan asap, kandungan benzopiren tidak boleh lebih dari $11 \mathrm{~g} / \mathrm{kg}$ (Menden, 1990).

\section{Digoreng}

Umumnya menggunakan minyak panas dalam panci penggorengan (wajan). Minyak yang digunakan diusahakan sesedikit mungkin jika digunakan untuk menggoreng bahan pangan berlemak tinggi, misalnya 
daging ayam, karena lemak yang terkandung dalam bahan akan mencair dan bersatu dengan minyak penggorengan (llies, 1993). 


\section{METODE PENELITIAN}

\section{A. Waktu dan tempat}

Penelitian ini akan dilaksanakan pada pekan ke 4 Oktober, pekan 1 dan 2 November 2010. Di laboratorium Kimia dan analisa, IImu dan teknologi Pangan, Fakultas pertanian, Unhas

\section{B. Metode Penelitian}

\section{A. Pengolahan}

Penelitian ini dilakukan dengan mengolah ikan gabus dengan cara dimasak, goreng dan panggang. Langkah-langkah pengolahannya sebagai berikut :

\section{Dimasak}

1. Ikan gabus ditimbang kemudian dibersihkan/disiangi (dibuang sisik, isi perut, insang, dan siripnya).

2. Dipotong-potong sesuai selera kemudian dicuci sampai bersih.

3. Ikan yang telah bersih kemudian dimasukkan kedalam panci lalu di beri bumbu

4. Dimasak hingga matang. 


\section{Digoreng}

1. Ikan gabus ditimbang kemudian dibersihkan/disiangi (dibuang sisik, isi perut, insang, dan siripnya).

2. Dipotong-potong sesuai selera kemudian dicuci sampai bersih.

3. Kemudian digoreng dalam minyak yang mendidih hingga matang.

\section{Dibakar}

1. Ikan gabus ditimbang kemudian dibersihkan/disiangi (dibuang sisik, isi perut, insang, dan siripnya).

2. Dipotong-potong sesuai selera kemudian dicuci sampai bersih.

3. Kemudian ikan dipanggang di atas bara api hingga matang.

\section{B. Pengujian Kadar Protein Albumin (Metode Lowry)}

Kadar protein dianalisa menggunakan metode Lowry dengan cara sebagai berikut : 


\section{Pereaksi}

1. Natrium karbonat 2 gram dalam $500 \mathrm{ml}$ larutan $\mathrm{NaOH} 0,1$ $\mathrm{mol} / \mathrm{L}$

2. Tembaga Sulfur 0,5 gram dalam $100 \mathrm{ml}$ larutan Na-K tartarat 1\% (dibuat hanya pada waktu akan digunakan)

3. Campuran $50 \mathrm{ml}$ pereaksi (1) dengan $1 \mathrm{ml}$ Pereaksi (2) (hanya pada waktu akan digunakan, hanya stabil selama 1 hari).

4. Pereaksi Folin Ciocalteau (pereaksi fenol). Biasanya tersedia secara komersial, larutan dengan aquades 1:1 sebelum digunakan.

5. Larutan protein standar : $0,02 \mathrm{mg} / \mathrm{ml}$ Bovine serum albumin (BSA)

\section{Pembuatan Kurva Standar}

1. Dimasukkan kedalam tabung reaksi : 0 (blangko), $0,1,0,2$, $0,3,0,4,0,6,0,7,0,8$ dan $1 \mathrm{ml}$ protein standar. Tambah air sampai volume total masing-masing $4 \mathrm{ml}$. Dalam masing- 
masing tabung reaksi ditambahkan $5 \mathrm{ml}$ pereaksi (3), campur merata dan biarkan 10-15 menit pada suhu kamar.

2. Ditambakan $0,5 \mathrm{ml}$ pereaksi (4) kedalam masing-masing tabung reaksi, kocok merata dengan cepat sesudah penambahan.

3. Dibiarkan kurang lebih 30 menit sampai warna biru terbentuk.

4. Ukur absorbsinya pada $650 \mathrm{~nm}$.

5. Buat kurva standar.

\section{Persiapan Sampel}

Sampel harus berupa cair. Jika berbentuk padatan maka harus dihancurkan dulu dan ditambahkan air. Hancuran yang diperoleh disaring lalu disentrifuge. Perhatikan faktor pengenceran.

Penetapan Sampel

0,1 - $1 \mathrm{ml}$ sampel dipipet. Masukkan ke dalam tabung reaksi, kemudian diperlakukan seperti penentuan standar. 


\section{HASIL DAN PEMBAHASAN}

A. Hasil

\section{Kurva standar}

Tabel 1. Kurva standar BSA

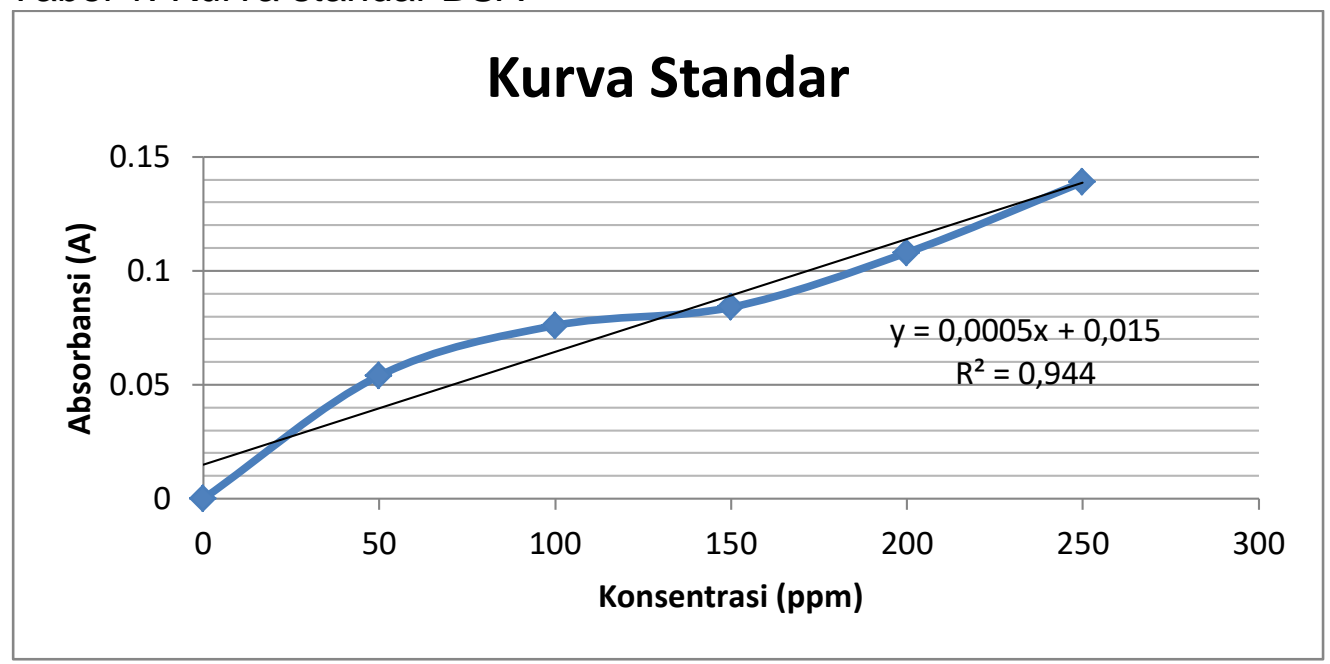

\section{Hasil Pengukuran}

Tabel 2. Hasil pengukuran albumin ikan gabus pada beberapa olahannya

\begin{tabular}{|c|c|c|c|c|c|c|}
\hline Sampel & $\begin{array}{l}\text { Absorbansi } \\
\text { (A) }\end{array}$ & $\begin{array}{l}\text { Konsentrasi } \\
\quad(\mathrm{ppm})\end{array}$ & $\begin{array}{c}\text { Rata-rata } \\
\text { Kosentrasi } \\
(\mathrm{ppm})\end{array}$ & $\begin{array}{c}\text { Konst } x \\
\text { Pengenceran } \\
(\mathrm{ppm} x \text { 150) }\end{array}$ & $\mathrm{mg} / \mathrm{ml}$ & $\mathrm{g} / 100 \mathrm{ml}$ \\
\hline $\begin{array}{c}\text { Ikan } \\
\text { Goreng I } \\
\end{array}$ & 0,158 & 286 & \multirow{2}{*}{314} & \multirow{2}{*}{47100} & \multirow{2}{*}{47,1} & \multirow{2}{*}{4,71} \\
\hline $\begin{array}{c}\text { Ikan } \\
\text { Goreng II }\end{array}$ & 0,186 & 342 & & & & \\
\hline $\begin{array}{c}\text { Ikan Masak } \\
\text { I }\end{array}$ & 0,146 & 262 & \multirow{2}{*}{247} & \multirow{2}{*}{37050} & \multirow{2}{*}{37,05} & \multirow{2}{*}{3,705} \\
\hline $\begin{array}{c}\text { Ikan Masak } \\
\text { II }\end{array}$ & 0,131 & 232 & & & & \\
\hline $\begin{array}{c}\text { Ikan Bakar } \\
\text { I }\end{array}$ & 0,253 & 476 & \multirow{2}{*}{348} & \multirow{2}{*}{52200} & \multirow{2}{*}{52,2} & \multirow{2}{*}{5,22} \\
\hline $\begin{array}{c}\text { Ikan Bakar } \\
\text { II }\end{array}$ & 0,125 & 220 & & & & \\
\hline
\end{tabular}




\section{B. Pembahasan}

Analisa Kadar protein terlarut (Albumin) yang ditunjukkan pada tabel 1 diatas menunjukkan bahwa kadar Albumin terendah terdapat pada perlakuan ikan gabus masak yaitu 3,705 gram/ $100 \mathrm{ml}$ sendangkan kadar albumin tertinggi terdapat pada perlakuan ikan gabus panggang yaitu 5, 22 gram/100 ml.

Hasil analisa sidik ragam terhadap kadar albumin ikan gabus dari beberapa cara pengolahan menunjukkan bahwa berbeda tidak nyata pada taraf $5 \%$ dan $1 \%$. Hal ini berarti terdapat perbedaan namun tidak nyata terhadap perlakuan yang satu dengan yang lain dari kadar albumin yang dihasilkan.

\section{Ika n Goreng}

Hasil Pengukuran kadar albumin ikan gabus goreng diperoleh hasil absorbansi 0,158 dan 0,186 . Dengan memasukkan nilai tersebut ke persamaan yang diperoleh dari pengukuran kurva standar yaitu $y=$ $0,0005 x+0,015$ sehingga diperoleh 286 ppm dan 342 ppm kemudian dikalikan dengan banyaknya pengenceran maka diperoleh nilai kadar albumin bahan yaitu 4,71 $\mathrm{g} / 100 \mathrm{ml}$. Kadar albumin ikan gabus segar menurut Hasil penelitian Johanes Cavallo (1998), kandungan albumin per $100 \mathrm{cc}$ ikan gabus adalah 6,224 gram. Hal ini dikarenakan selama 
dilakukan pengolahan berupa penggorengan, memungkinkan kehilangan atau kerusakan albumin. Di samping itu kehilangan albumin juga bisa terjadi selama preparasi yaitu pada saat pencucian, pengirisan.

\section{Ikan Masak}

Hasil pengukuran kadar albumin ikan masak menunjukkan nilai absorbansi pada spektrofotometer yaitu 0,146 dan 0,131 . Setelah dimasukkan ke dalam persamaan $y=0,0005 x+0,015$ sehingga diperoleh konsentrasi yaitu 262 ppm dan 323 ppm. Setelah konsentrasi tersebut dikalikan dengan banyaknya pengenceran maka diperoleh kadar albumin bahan 3,705 g/100ml. Nilai ini jauh dari kadar albumin ikan gabus sedar menurut hasil penelitian Johannes Cavallo, (1998), kandungan albumin per 100ml ikan gabus adalah 6,224 gram dan anonim (2003), manfaat yang terdapat pada ikan gabus diantaranya adalah tingginya kadar protein (25,5\%) dan albumin $(6,2 \%)$ yang dapat bermanfaat dengan cepat sebagai penyembuhan luka. Kehilangan kadar albumin ini dimungkinkan terjadi pada saat preparasi sampel dan pada saat pemasakan. Karena albumin adalah protein larut air sehingga dapat hilang pada saat pencucian dan larut dalam air pada saat dimasak. 


\section{Ikan Bakar}

Hasil pengukuran kadar albumin ikan gabus goreng diperoleh hasil absorbansi 0,253 dan 0,125. Dengan memasukkan nilai tersebut ke persamaan yang diperoleh dari pengukuran kurva standar yaitu $\mathrm{y}=$ $0,0005 x+0,015$ sehingga diperoleh 476 ppm dan 220 ppm kemudian dikalikan dengan banyaknya pengenceran maka diperoleh nilai kadar albumin bahan yaitu $5,22 \mathrm{~g} / 100 \mathrm{ml}$. Kadar albumin ini lebih tinggi dibandingkan dengan hasil pengukuran kadar albumin ikan bakar dan ikan goreng. Namun masih lebih rendah dari kadar albumin ikan gabus segar menurut hasil penelitian Johanes Cavallo (1998), kandungan albumin per $100 \mathrm{ml}$ ikan gabus adalah 6,224 gram. Hal ini dikarenakan selama dilakukan preparasi bahan memungkinkan kehilangan albumin yaitu pada saat pencucian, pengirisan. 


\section{KESIMPULAN DAN SARAN}

\section{A. Kesimpulan}

Dari hasil praktikum dapat disimpulkan bahwa kandungan albumin ikan gabus tertinggi terdapat pada olahan dengan di panggang yaitu 5,22 g/100ml. Sedangkan kandungan ikan gabus terendah terdapat pada olahan dengan cara dimasak yaitu 3,705.

B. Saran

Saran untuk penelitian selanjutnya adalah sebaiknya dilakukan analisa kadar albumin untuk berbagai olahan ikan gabus lainnya, seperti biskuit ikan gabus, bakso ikan gabus, otak-otak ikan gabus dan lain-lain. 


\section{DAFTAR PUSTAKA}

Anonim, 2003. Gabus Temuan Sang Profesor. http://www.gatra.com. Akses 17 Februari 2006

Anonim, 2003. Ikan Gabus Untuk Luka Operasi. http://www.kompas.com. Akses 17 Februari 2006

Anonim, 2005. Protein Plasma. Akses 17 Februari 2006 http://www.klinikku.com/pustaka/lab/hati/protein darah.html.

Anonim, 2005. Fish Protein Concentrate, Fish Flour, Fish Hydrolyzate. http://www.fao.org/WAICENT/Faolnfo/Agricult/agA/AGAP/FRG/AFRIS/ Data/334.HTM. Akses 19 Februari 2006

Afrianto, E dan E, Liviawati, 1989. Pengawetan dan Pengolanan Ikan. Penerbit Kanisius, Yogyakarta.

Aisyah. 2008. Spektrofotometer. Rgm_aisyah's Blog. [terhubung berkala]. http://rgmaisyah. wordpress.com/ 2008/ 11/ 25/ spektrofotometer/ [28Maret 2010].

Bijaksana, Untung., 2004. Ikan "Haruan" Di Perairan Rawa Kalimantan Selatan. Makalah Pengantar Falsafah Sains (PPS 702). Sekolah Pasca Sarjana/S3. Institut Pertanian Bogor.

Brotowijoyo, M.D. 1995. Pengantar Lingkungan dan Budidaya Air. Liberty. Jogjakarta.

Cahyanto. 2008. Tinjauan Spektrofotometer. Xains Info. [terhubung berkala].http://xains-info.blogspot.com/ 2008/ 08/ tinjauanspektrofototmeter. html[24 Maret 2010.

Crespo, J.C., Gonvales, A.L., Elisabeth, S., Grellet, A.P.Y. Lopes 2000. Albumin Purification From Human Placenta. Biotechnology Appl Biochem. 31,1001-006.

Djuhanda, Tatang. 1987. Dunia Ikan. Armico. Bandung.

Hadi Anim. 2009. Spektrofotometri. Tjah Kimai Unnes. [terhubung berkala].http://tjahkimiaunnes.blogspot.com/ spektrofotometri. html [24IMaret 2010]. 
Hart. 2003. Organical Chemistry. United States : Mac Graw Hill.

llies, A., 1993. Gesund Und Fit Leben, Midena Verlag, Kuettigen, Aarau. di dalam Mahendradatta, M., 2007. Pangan Aman dan Sehat, LEPHAS

llyas, S., 1980. Teknologi Refrigerasi Hasil Perikanan I Lembaga Teknologi Perikanan, Jakarta.

Keenan R. 1992. Kimia untuk Universitas. Jakarta : Erlangga.

Khopkar S. 2007. Konsep Dasar kimia Analitik. Jakarta : UI Press.

Johanes, Capallo. 1998. Studi Profil Asam Amino Albumin dan Mineral Zn pada Ikan Gabus (Ophichepalus striatus) dan Ikan Tomang. Fakultas Perikanan Unibraw. Malang.

Makfoed, Djarir., Djagal W.M., Pudji Hastuti, Sri Anggrahini, Sri Raharjo, Sudarmanto Sastrosuwignyo, Suhardi, Soeharsono M., Suwedo Hadiwiyoto dan Tranggono, 2002, Kamus Istilah Pangan dan Gizi. Kanisius, Yogyakarta.

Menden, E., 1990. Di Ernaehrung, Meyers lexikonverlag, Mannheim-WienZuerich. Di dalam Mahendradatta, M., 2007. Pangan Aman dan Sehat, LEPHAS

Mizer, David A., Mary Porter, Beth Sonier, Karen Eich Drummond, 2000. Food Preparation For The Profesional, 3rd ed. John Wiley \& Sons, Inc. New York.

Peters, T. 1997. All About Albumin, Biocemestry, Genetics and Medical Application, Academic Press, New York.

Riyadi W. 2008. Perbedaan Spektrometri dan Spektrofotometri. Wahyu Riadi.[terhubung berkala]. http://wahyuriyadi.blogspot.com/ 2008/ 10/perbedaan spektrometri-dan.html [24 Maret 2010].

Rohman. 2007. Kimia Farmasi Analisis. Yogyakarta : Pustaka Pelajar.

Tahir, M., 1997. Studi Pembuatan abon Ikan Gabus. Teknologi Pertanian Universitas Hasanuddin, Makassar. 
Schwedt, George., 2005. Taschenatlas der Lebensmittelchemie. WILEY-VCH Verlag, Weinheim., di dalam Mahendradatta, M., 2007. Pangan Aman dan Sehat, LEPHAS

Suprayitno, Eddy., 2003. Potensi Serum Albumin Dari Ikan Gabus (Ophiocephalus streatus). Fakultas Perikanan, Universitas Brawijaya, Malang.

Vieira, Ernst. R., 1996. Elementary Food Science. 4th Edition, Chapman and Hall, New York.

Weber dan Beaufort (1922), direvolusi oleh $\mathrm{Ng}$ dan Li di dalam Kottelat et al., (1993), di dalam Bijaksana (2004) 


\section{LAMPIRAN}

Lampiran 1. Tabel Hasil Pengukuran kadar albumin Ikan Gabus

\begin{tabular}{|c|c|c|c|c|}
\hline \multirow{2}{*}{ Perlakuan } & \multicolumn{2}{|c|}{ Ulangan } & \multirow{2}{*}{ Jumlah } & Rata-rata \\
\cline { 2 - 4 } & 1 & 2 & & \\
\hline Ikan Bakar & 7,14 & 3,3 & 10,44 & 5,22 \\
\hline Ikan Masak & 3,93 & 3,48 & 7,41 & 3,705 \\
\hline Ikan G & 4,29 & 5,13 & 9,42 & 4,71 \\
\hline & & & 27,27 & \\
\hline
\end{tabular}

Lampiran 2. Tabel Analisa Sidik Ragam Terhadap Kadar albumin ikan gabus

\begin{tabular}{|l|r|r|l|l|l|l|}
\hline SK & db & JK & KT & F hit & F 5\% & F 1\% \\
\hline Perlakuan & 1 & 2,3769 & 2,3769 & $0,911056^{\text {tn }}$ & 10,13 & 34,12 \\
\hline Galat & 3 & 7,82685 & 2,60895 & & \\
\hline Total & 4 & \multicolumn{5}{|l|}{} \\
\hline
\end{tabular}

tn : berbeda tidak nyata pada taraf $5 \%$ dan $1 \%$ 